\title{
Annual Rainfall and Dryland Cotton Lint Yield-Southern High Plains of Texas
}

\author{
Robert J. Lascano ${ }^{*}\left(\mathbb{D}\right.$, Paxton Payton², James R. Mahan², Timothy S. Goebel², Dennis C. Gitz III ${ }^{1}$ \\ ${ }^{1}$ Wind Erosion and Water Conservation Research Unit, USDA-ARS, Lubbock, TX, USA \\ ${ }^{2}$ Plant Stress and Germplasm Development Research Unit, USDA-ARS, Lubbock, TX, USA \\ Email: *Robert.Lascano@usda.gov
}

How to cite this paper: Lascano, R.J., Payton, P., Mahan, J.R., Goebel, T.S. and Gitz III, D.C. (2022) Annual Rainfall and Dryland Cotton Lint Yield-Southern High Plains of Texas. Agricultural Sciences, 13, 177-200.

https://doi.org/10.4236/as.2022.132014

Received: December 8, 2021

Accepted: February 11, 2022

Published: February 14, 2022

Copyright $\odot 2022$ by author(s) and Scientific Research Publishing Inc. This work is licensed under the Creative Commons Attribution International License (CC BY 4.0).

http://creativecommons.org/licenses/by/4.0/ (c) (i) Open Access

\begin{abstract}
Agriculture in the Texas High Plains (THP) is in a transition phase of producing crops with a diminishing supply of irrigation-water from the Ogallala aquifer to dryland production systems. This shift is driven by the fact that the depth to the water table of the Ogallala aquifer continues to increase. Dryland cotton production systems are prevalent in the southern counties of the THP and our purpose was to use the long-term dryland cotton lint yields from these counties as precursors of the future cotton production patterns that will emerge in this region. For this purpose, from 1972 to 2018, we calculated the ratio of dryland cotton lint yield per unit of annual rainfall at the county level. This ratio is called crop water productivity $(C W P)$ and has units of mass per unit volume $\left(\mathrm{g} / \mathrm{m}^{3}\right)$. In our analysis, we used cotton lint yield data provided by the National Agricultural Statistics and rainfall data provided by the $\mathrm{Na}$ tional Oceanic and Atmospheric Administration. Our results indicated that the three datasets used in our analysis, i.e., cotton lint yield, rainfall and $C W P$ were all normally distributed. In this time period, 1972 to 2018, only one year 2011-a year with a record drought of $179 \mathrm{~mm}$ of rain failed to produce a dryland cotton crop in all the counties used in our analysis. The mean cotton lint yield \pm standard deviation ranged from a high of $400 \pm 175 \mathrm{~kg} / \mathrm{ha}$ in Lubbock County to a low of $252 \pm 144 \mathrm{~kg} / \mathrm{ha}$ in Andrews County. However, the counties with the largest $C W P>90 \mathrm{~g} / \mathrm{m}^{3}$ were Glasscock, Midland and Martin County. The importance of this result is that these counties are in the southern region of the THP and are subject to extreme environmental conditions and yet cotton producers manage to produce a cotton crop in most years. We conclude that management production methods used by these dryland producers represent the future schemes that will need to be adopted in other counties to sustain the emerging dryland cropping systems across the THP.
\end{abstract}




\section{Keywords}

Crop Water Productivity, Cotton Cropping Systems, Crop Management, Rainfed, Ogallala Aquifer, Water Use Efficiency

\section{Introduction}

The effect of water, from either precipitation and/or irrigation, on the cropping systems of the Texas High Plains (THP) has been the subject of early and numerous studies. For example, the impact of irrigation was documented in 1921 by E. P. Arneson [1] and the history of irrigation given by [2] and by [3] providing many examples of research on this subject. Likewise, studies on the relation between precipitation and cotton production are given by [4] [5] [6] and by others. Further, the history of irrigated agriculture in the THP is well documented and summaries are given by [1] [7] and by [8].

The development of current cropping systems in the THP is closely related to the introduction of irrigation-water from the Ogallala aquifer, a large aquifer that covers eight states of the Great Plains of the USA [9]. In the THP, the Ogallala aquifer is classified as a closed system, where the withdrawal of water exceeds recharge and thus with time the depth to the water table has increased [10] [11]. The average increase is about $0.3 \mathrm{~m} /$ year and on average the depth to the water table has increased by approximately $15 \mathrm{~m}$ since measurements started in 1969 [12]. The overall consequence of the decline of the water table from the Ogallala aquifer has been a gradual transition from crop production using irrigation to dryland production [10] [13] [14] [15]. Given the decline of the water table and the increase of the cost associated to pump the remaining irrigation-water infers that in the future, more of the crop production in the THP will derive from dryland cropping systems [9]. For our purpose, we define dryland farming as crop production without irrigation and in a semiarid environment [9].

In recent studies by [16] [17] [18] [19] [20] and by [21], it was discussed that the longevity of the Ogallala aquifer could be extended by converting fully irrigated center pivots to $50 \%$ to $75 \%$ dryland production and also by optimizing crop management practices when adopting dryland production schemes. Some of these practices include circular planting [22], use of furrow dikes [23] [24], crop rotations and crop residues [25] [26], and minimum tillage [27]. Further, it was suggested that the key factor to enhance dryland production was to capture precipitation and store this water in the profile [28]. Specifically, in the emerging dryland cropping systems of the THP, the emphasis is to capture and to retain precipitation throughout the year and mainly during the growing season.

In the THP, the average long-term rainfall is about $460 \mathrm{~mm}$ and most of the rain falls during the growing season; however, both the monthly and annual pattern are variable. The annual standard deviation for rainfall exceeds $150 \mathrm{~mm}$ 
and the monthly coefficient of variation (CV) exceeds 60\% [9] [29]. Further, the capture and storage of rain in the soil is a function of the soil physical properties that affect infiltration and runoff, and of the rainfall rate and amount. Measurements of the rainfall rate and frequency of storms for a location in the THP indicate that about $70 \%$ of rain events are $<6 \mathrm{~mm}$ and $86 \%$ of events are $<13 \mathrm{~mm}$ [30]. The relevancy of this result is that attempting to establish a relation between annual precipitation and crop yield is complicated by the fact that rain events $<6 \mathrm{~mm}$ are a large contributor of the overall input of water and thus it is difficult to assess how much of this rainfall is stored in the soil and is either available for crop use or is lost to evaporation of water from the soil. Further, $6 \%$ of the total rain events are between 25 and $50 \mathrm{~mm}$ and the runoff generated from such storms is estimated to be $50 \%$ or higher [31]. Thus, establishing a relation between seasonal rainfall and crop yield is not straightforward, as it is difficult to get an accurate estimate of the weekly and monthly amount of rain that may be stored in the soil and subsequently used by the crop.

Dryland cropping systems are prevalent in the southern counties of the THP (Figure 1) as evidence of the decline of irrigation-water from the Ogallala aquifer. As this trend continues it is important to understand the relation between rainfall and cotton lint yield. Therefore, our objective was, on first analysis, to establish a relation between measured annual precipitation and reported values of cotton lint yield for dryland production at the county level. For this purpose we selected sixteen counties of the THP delineated by the red line boundary shown in Figure 1. In our analysis we used weather data from the National Oceanic and Atmospheric Administration and dryland cotton lint yield data provided by the National Agricultural Statistics, USDA. The southern counties of the THP were selected as precursors of future cotton production patterns that will emerge as the overall cotton production in the THP will be skewed towards dryland production systems.

\section{Materials and Methods}

\subsection{Area of Study}

The study area, about $40,000 \mathrm{~km}^{2}$, consists of sixteen counties and represents the southern boundary of the Great Plains that extend from Canada to south USA. The counties in the THP's are delineated by the red line that demarks their periphery as shown in Figure 1. Also given is the approximate boundary of the Ogallala aquifer (blue shade) as reported by the Texas Water Development Board [32]. Note that towards the eastern and southern counties (Crosby, Garza, Borden, Howard, Glasscock and Midland) and as expected, the extent of the Ogallala aquifer diminishes.

The county name and seat, year founded, area, and elevation of the county seat is given in Table 1 . In general, most counties are about $2300 \mathrm{~km}^{2}$ in area. The smallest county is Cochran with $2007 \mathrm{~km}^{2}$ and the largest county is Gaines with $3893 \mathrm{~km}^{2}$ closely followed by Andrews with an area of $3888 \mathrm{~km}^{2}$. The oldest 
Table 1. County name and seat, year founded, and area for the sixteen counties of the THP shown in Figure 1. Also given is the elevation of the county seat and the last column denotes the extent of the Ogallala aquifer in each county.

\begin{tabular}{|c|c|c|c|c|c|}
\hline County & Seat & $\begin{array}{c}\text { Year } \\
\text { Founded }\end{array}$ & $\begin{array}{c}\text { Area } \\
{\left[\mathrm{km}^{2}\right]}\end{array}$ & $\begin{array}{c}\text { Elevation }^{+} \\
{[\mathrm{m}]}\end{array}$ & $\begin{array}{l}\text { Ogallala } \\
\text { Aquifer }\end{array}$ \\
\hline Andrews & Andrews & 1910 & 3888 & 969 & Marginal \\
\hline Borden & Gail & 1876 & 2347 & 779 & Marginal \\
\hline Cochran & Morton & 1924 & 2007 & 1147 & Yes \\
\hline Crosby & Crosbyton & 1886 & 2336 & 922 & Yes \\
\hline Dawson & Lamesa & 1905 & 2336 & 912 & Yes \\
\hline Gaines & Seminole & 1905 & 3893 & 1005 & Yes \\
\hline Garza & Post & 1907 & 2321 & 794 & Marginal \\
\hline Glasscock & Garden City & 1893 & 2334 & 804 & Marginal \\
\hline Hockley & Levelland & 1921 & 2354 & 1073 & Yes \\
\hline Howard & Big Spring & 1882 & 2341 & 744 & Marginal \\
\hline Lubbock & Lubbock & 1891 & 2334 & 978 & Yes \\
\hline Lynn & Tahoka & 1903 & 2313 & 939 & Yes \\
\hline Martin & Stanton & 1884 & 2372 & 811 & Marginal \\
\hline Midland & Midland & 1885 & 2336 & 847 & Marginal \\
\hline Terry & Brownfield & 1904 & 2308 & 1009 & Yes \\
\hline Yoakum & Plains & 1907 & 2072 & 1111 & Yes \\
\hline
\end{tabular}

+https://elevation.maplogs.com/poi/gail tx usa.36177.html.

county is Borden, founded in 1876, and Andrews is the youngest county, founded in 1910. In terms of elevation, the county seats decrease about $250 \mathrm{~m}$ from both north to south and from west to east. The highest elevation is $1147 \mathrm{~m}$ in Morton, county seat for Cochran and the lowest elevation is $744 \mathrm{~m}$ in Big Spring, county seat for Howard (Table 1).

The dominant soil orders in the THP are Alfisols in the northern counties and Aridisols in the southern counties. Soils tend to be sandier in the southern region and finer-textured soils are predominant in the northern region of the THP [29]. There are two soil groups in the north, which include the following soil series: Pullman-Randall-Lofton and Amarillo-Acuff-Olton. In the south there is one main group that includes the soil series: Patricia-Brownfield-Nutivoli [33]. The area is characterized by deep soils with accumulations of clay, and of calcium and magnesium carbonate in sub-soil horizons. These accumulations of calcium and magnesium carbonate are known as caliche [34] [35] and play an important role in the storage of rainfall in the soil profile [9] for dryland production. 


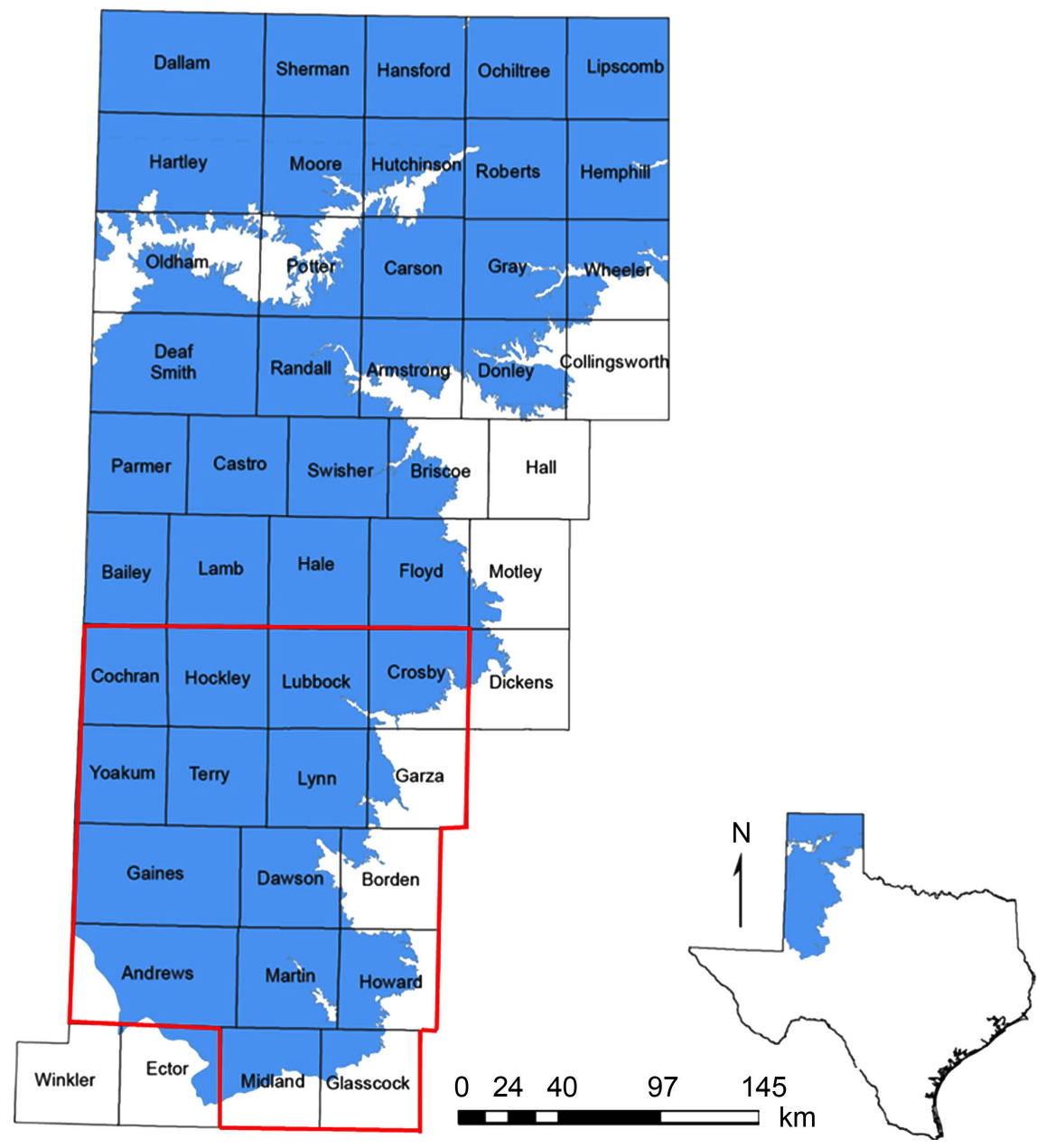

Figure 1. Sixteen counties in north Texas used in the analysis of dryland cotton lint production. The blue area demarks the approximate boundary of the Ogallala aquifer in each county of this region [32].

\subsection{Calculation of Crop Water Productivity (CWP)}

The ratio of cotton lint yield $(\mathrm{kg} / \mathrm{ha})$ to evapotranspiration $(E T, \mathrm{~mm})$ is referred to as water use efficiency (WUE) and as crop water productivity (CWP), and both terms have units of mass per unit volume, i.e., $\mathrm{kg} / \mathrm{ha} / \mathrm{mm}=0.1 \mathrm{~kg} / \mathrm{m}^{3}=100$ $\mathrm{g} / \mathrm{m}^{3}$. The use of either term, WUE or $C W P$, to reflect crop production has limitations [36] [37] [38]. However, the term $C W P$ is preferred over WUE as this metric, i.e., efficiency, implies that both numerator and denominator have the same units, e.g., mass per unit mass $(\mathrm{kg} / \mathrm{kg})$ or volume per unit volume $\left(\mathrm{m}^{3} / \mathrm{m}^{3}\right)$. An example of a true WUE for cotton of $3.7 \mathrm{~g}$ lint per $\mathrm{kg}$ of water transpired is given by [39]. Nonetheless, for our analysis we selected and used $C W P$ to calculate the ratio of cotton lint yield per unit land area $\left(\mathrm{kg} / \mathrm{m}^{2}\right)$ and per unit of evapotranspiration (m), i.e., $\mathrm{kg} / \mathrm{m}^{3}$. Thereafter, and for convenience we use $\mathrm{g} / \mathrm{m}^{3}$ as the unit for $C W P$. In the following sections we first describe the numerator (cotton lint yield) and thereafter describe the denominator (ET), used to calculate $C W P$ as follows: 


$$
C W P=\text { Cotton Lint Yield } / E T
$$

Numerator-Cotton Lint Yield. A record of the values of dryland cotton lint yield for each of the sixteen counties (Figure 1) from 1972 to 2018 is given on Table 2. This time span represents 36 to 46 values of annual dryland lint yield and this number varies by county. For example, the record for Crosby County from 1972-2018 is for 46 values, and for Midland County, the record is 36 values for the span from 1972 to 2010 . Further, missing lint yield values for each county are also listed in Table 2. For example, Borden and Midland counties have 11 years were lint yield values are not given likely due to lack of rainfall during those years. The source of this lint yield data is the National Agricultural Statistics Service (NASS) [40]. Values for each county are reported as Cotton Upland Non-Irrigated Yield in Lbs/Acre, which were converted to $\mathrm{kg} / \mathrm{ha}$ (1.0 Lb/Acre = $1.12 \mathrm{~kg} / \mathrm{ha}$ ). Examples of dryland lint yield values in $\mathrm{kg} / \mathrm{ha}$ from the NASS website for Crosby, Dawson, Lubbock, Martin and Midland counties are given in Table 3. Please note that in all these five counties the cotton lint yield for 2011, is blank, i.e., null value, which was a year with record-low annual rainfall, implying that no dryland cotton was harvested. Also, for Midland County, over a

Table 2. Record of annual dryland cotton lint yield production for each of the sixteen counties in the THP (Figure 1) used in our analysis.

\begin{tabular}{|c|c|c|c|}
\hline \multirow{2}{*}{ County } & \multicolumn{3}{|c|}{ Record of Dryland Cotton Lint Yield ${ }^{+}$} \\
\hline & Span & Number of Years & Number of Missing Years \\
\hline Andrews & $1972-2010$ & 36 & 8 \\
\hline Borden & $1972-2009$ & 36 & 11 \\
\hline Cochran & $1972-2018$ & 40 & 7 \\
\hline Crosby & $1972-2018$ & 46 & 3 \\
\hline Dawson & $1972-2018$ & 45 & 2 \\
\hline Gaines & $1972-2018$ & 44 & 1 \\
\hline Garza & $1972-2018$ & 44 & 3 \\
\hline Glasscock & $1972-2017$ & 45 & 2 \\
\hline Hockley & $1972-2017$ & 44 & 3 \\
\hline Howard & $1972-2016$ & 42 & 5 \\
\hline Lubbock & $1972-2018$ & 46 & 1 \\
\hline Lynn & $1972-2018$ & 46 & 1 \\
\hline Martin & $1972-2018$ & 45 & 1 \\
\hline Midland & $1972-2010$ & 36 & 11 \\
\hline Terry & $1972-2017$ & 45 & 3 \\
\hline Yoakum & $1972-2017$ & 42 & 5 \\
\hline
\end{tabular}

+https://quickstats.nass.usda.gov/results/23F8D121-7F98-3A1A-9ABA-E0EF835A5302. 
Table 3. Upland non-irrigated dryland lint yield $(\mathrm{kg} / \mathrm{ha})$ values as a function of year from 1972 to 2018 for Crosby, Dawson, Lubbock, Martin and Midland counties in the THP (Source: [40]). The number of values (n) for each county is given as the last row.

\begin{tabular}{|c|c|c|c|c|c|}
\hline \multirow{2}{*}{ Year } & \multicolumn{5}{|c|}{ Upland Non-Irrigated Cotton Yield [kg/ha] } \\
\hline & Crosby & Dawson & Lubbock & Martin & Midland \\
\hline 1972 & 661 & 504 & 464 & 334 & 305 \\
\hline 1973 & 480 & 555 & 436 & 666 & 392 \\
\hline 1974 & 143 & 142 & 171 & 149 & 166 \\
\hline 1975 & 285 & 258 & 260 & 451 & 382 \\
\hline 1976 & 386 & 475 & 298 & 498 & 371 \\
\hline 1977 & 432 & 405 & 517 & 409 & 353 \\
\hline 1978 & 188 & 157 & 243 & 198 & 194 \\
\hline 1979 & 449 & 473 & 438 & 616 & 565 \\
\hline 1980 & 150 & 145 & 156 & 123 & 102 \\
\hline 1981 & 343 & 447 & 372 & 489 & 392 \\
\hline 1982 & 184 & 322 & 245 & 345 & 351 \\
\hline 1983 & 224 & 245 & 312 & 231 & 330 \\
\hline 1984 & 295 & 288 & 389 & 210 & 309 \\
\hline 1985 & 338 & 349 & 280 & 420 & 356 \\
\hline 1986 & 345 & 208 & 203 & 176 & 290 \\
\hline 1987 & 423 & 395 & 514 & 554 & 370 \\
\hline 1988 & 355 & 544 & 456 & 575 & 461 \\
\hline 1989 & 272 & 288 & 318 & 345 & 243 \\
\hline 1990 & 318 & 498 & 405 & 545 & 396 \\
\hline 1991 & 284 & 303 & 299 & 358 & 268 \\
\hline 1992 & 369 & 465 & 582 & 576 & 462 \\
\hline 1993 & 351 & 436 & 455 & 544 & 368 \\
\hline 1994 & 333 & 223 & 347 & 322 & 268 \\
\hline 1995 & 241 & 295 & 280 & 266 & 216 \\
\hline 1996 & 382 & 223 & 510 & 306 & 262 \\
\hline 1997 & 396 & 377 & 326 & 465 & 373 \\
\hline 1998 & 402 & 343 & 225 & 269 & 371 \\
\hline 1999 & 294 & 340 & 319 & 313 & 174 \\
\hline 2000 & 225 & 256 & 167 & 252 & 187 \\
\hline 2001 & 180 & 235 & 206 & 126 & 154 \\
\hline 2002 & 268 & 323 & 347 & 272 & 168 \\
\hline
\end{tabular}




\begin{tabular}{|c|c|c|c|c|c|}
\hline Continued & & & & & \\
\hline 2003 & 196 & 330 & 250 & 300 & 254 \\
\hline 2004 & 651 & 565 & 721 & 398 & 303 \\
\hline 2005 & 572 & 599 & 807 & 620 & 469 \\
\hline 2006 & 223 & 287 & 211 & 294 & 207 \\
\hline 2007 & 718 & 621 & 935 & 798 & \\
\hline 2008 & 344 & 368 & 525 & 445 & \\
\hline 2009 & 383 & 409 & 411 & 467 & \\
\hline 2010 & 526 & 501 & 644 & 494 & 371 \\
\hline 2011 & & & & & \\
\hline 2012 & 355 & 342 & 306 & 417 & \\
\hline 2013 & 383 & & 488 & 272 & \\
\hline 2014 & 428 & 335 & 367 & & \\
\hline 2015 & 486 & 465 & 611 & 397 & \\
\hline 2016 & 541 & 493 & 709 & 501 & \\
\hline 2017 & 560 & 534 & 551 & 519 & \\
\hline 2018 & 238 & 540 & 342 & 398 & \\
\hline $\mathrm{n}$ & 46 & 45 & 46 & 45 & 36 \\
\hline
\end{tabular}

12-year span, between 2007 and 2018, dryland cotton was only harvested and reported in 2010. Midland County is the southmost county of our study area.

Denominator-Evapotranspiration (ET). In general, the relationship between crop water use and yield is linear when water is the only limiting factor, and it may be quantified by the water balance of the cropping system with appropriate boundary conditions. A one-dimensional annual water balance is given by the sum of inputs and outputs:

$$
\text { Rain }+ \text { Irrigation }+ \text { Runon }=E_{s}+E_{c}+\text { Runoff }+ \text { Drainage }+\Delta \text { Storage }
$$

where annual inputs are Rain, Irrigation and Runon and annual losses are evaporation of water from the soil $\left(E_{s}\right)$ and crop $\left(E_{c}\right)$, i.e., transpiration $(T)$, and their sum $\left(E_{s}+E_{c}\right)$ is evapotranspiration (ET); Runoff, Drainage, and $\triangle$ Storage is the annual change of water storage in the profile. In general, the boundary conditions for a crop are set at a screen-height of $2 \mathrm{~m}$ above the soil surface and a depth of $2 \mathrm{~m}$ below the soil surface. All terms in the water balance equation have units of volume of water per unit ground area, i.e., $\mathrm{mm}$.

As previously noted, we define a dryland system as a crop production without irrigation [9] and thus in Equation (2) the difference between a dryland and an irrigated cropping system is given by the inclusion of the irrigation term. Further, the input Rain through the infiltration process can either store water in the soil ( $\Delta$ Storage) or lose water as Runoff. Collectively, this is referred to as effec- 
tive rain, i.e., the net amount of water from a rain event that is stored in the soil. Drainage is water that moves below the root zone and Runon is surface water that moves from adjacent fields and both these terms for the semiarid conditions of the THP are assumed to be negligible. Thus, the annual water balance for a dryland cropping system and from Equation (2) simplifies to the sum of ET and $\Delta$ Storage:

$$
\text { Rain }_{\text {effective }}=E T+\Delta \text { Storage }
$$

A further and an important assumption made is that in dry environments (semiarid and arid) and on annual basis is that no rainfall is stored in the soil as it is quickly used by the plants through ET, i.e., $\Delta$ Storage $\approx 0$ [41] [42] [43]. This assumption is particularly applicable to the THP where about $85 \%$ of the annual rain falls during the growing season from April to September [29]. Thus, Equation (3) further simplifies to:

$$
\text { Rain }_{\text {effective }}=E T
$$

In summary, assuming that Drainage, Runoff, Runon and $\Delta$ Storage are negligible for the annual water balance of a dryland cropping system in a semiarid climate allow us to use measured values of annual Rain as a surrogate for annual values of ET. Thus, we use Rain as the denominator to calculate $C W P$ in Equation (1).

\subsection{Rainfall Data}

As the source of rainfall data for each county in Figure 1, we used data given by the National Oceanic and Atmospheric Administration (NOAA) (https://www/ncdc.noaa.gov/cdo-web/). A summary of the number of weather stations, and period of coverage, in both time and percent, number of years, between 1972 and 2018, that rainfall data were not given for each county is given in Table 4. This represents the time-period where cotton lint yield data are reported (Table 2). All counties include at least two weather stations, Garza includes 5, Midland includes 7, and Lubbock includes 21 weather stations. Most counties have a $100 \%$ coverage over the measurement period, start to end, while Cochran has a $74 \%$ and Glasscock has a $76 \%$ coverage. In nine counties (Andrews, Borden, Dawson, Garza, Glasscock, Lubbock, Lynn, Midland and Terry) rainfall records start in 1911-1915. The longest record is from Crosby County, which is 126 years, and started in 1895 . The shortest record is 78 years, starting in 1943 in Howard County. For each county, the average of all the weather stations were used to calculate the annual value of rainfall and this was the value used as ET in Equation (1) to calculate $C W P$.

\subsection{Statistical Analysis}

All cotton lint yield and rainfall data were checked for normality and the four moments of these values were calculated, i.e., mean, variance (standard deviation), skewness and kurtosis. Normality was checked using the $\chi^{2}$ distribution 
Table 4. Weather station details for each county. Shown are the number of weather stations in each county, the period of record where precipitation was reported and the corresponding coverage (source: https://www.ncdc.noaa.gov/cdo-web/).

\begin{tabular}{cccccc}
\hline & \multicolumn{5}{c}{ Weather Station Details } \\
\cline { 2 - 6 } County & \multicolumn{5}{c}{ Period of Record - Precipitation } \\
\cline { 2 - 6 } & $\begin{array}{c}\text { Included No. } \\
\text { of Stations }\end{array}$ & Start & End & $\begin{array}{c}\text { Years missing } \\
(1972-2018)\end{array}$ & $\begin{array}{c}\text { Coverage } \\
(\%)\end{array}$ \\
\hline Andrews & 2 & $01-01-1914$ & $01-01-2018$ & 13 & 87 \\
Borden & 3 & $01-01-1913$ & $01-01-2021$ & 1 & 100 \\
Cochran & 2 & $01-05-1936$ & $01-01-2020$ & 9 & 74 \\
Crosby & 3 & $01-01-1895$ & $01-01-2020$ & 0 & 100 \\
Dawson & 2 & $01-01-1911$ & $01-01-2017$ & 6 & 81 \\
Gaines & 2 & $01-01-1923$ & $01-01-2020$ & 4 & 87 \\
Garza & 5 & $01-01-1911$ & $01-01-2020$ & 7 & 100 \\
Glasscock & 3 & $01-01-1913$ & $01-01-2020$ & 18 & 76 \\
Hockley & 4 & $01-01-1936$ & $01-01-2020$ & 2 & 100 \\
Howard & 6 & $01-01-1943$ & $01-01-2020$ & 3 & 100 \\
Lubbock & 21 & $01-01-1912$ & $01-01-2020$ & 0 & 100 \\
Lynn & 4 & $01-01-1914$ & $01-01-2020$ & 0 & 100 \\
Martin & 3 & $01-01-1941$ & $01-01-2020$ & 14 & 100 \\
Midland & 7 & $01-01-1912$ & $01-01-2020$ & 0 & 100 \\
\hline \multirow{2}{*}{ Terry } & 2 & $01-01-1915$ & $01-01-2020$ & 1 & 12 \\
\hline
\end{tabular}

function (CHIDIST) that calculates the right-tailed probability of this function, using a $p$-Value of 0.05 . The syntax for this function is $\operatorname{CHIDIST}(x, d f)$, where $x$ is the $\chi^{2}$ statistic and $d f$ are degrees of freedom. We tested the null hypothesis $\left(\mathrm{H}_{\mathrm{o}}\right)$ that the data is normally distributed using a $p$-Value of 0.05 . For all of our statistical calculations we used a spreadsheet and used two tools, i.e., histogram and descriptive statistics (Microsoft ${ }^{\circledR}$ Excel, version 16.17.27). The histogram tool charts the data by grouping the variable of interest into intervals, i.e., bins, of equal width. The descriptive statistics tool calculates the mean, standard error, median, mode, standard deviation, sample variance, kurtosis, skewness, range, maximum, minimum, sum, count, and the confidence level at a $95 \%$ for the data set values. We did not attempt to detrend the dryland upland county-level lint yield values as done for example, by [44].

\section{Results and Discussion}

This section is presented in the same sequence that was used to calculate values 
of crop water productivity $(C W P)$. First, we present results of dryland cotton lint yield; second, we report annual mean rainfall; and third, values of $C W P$, i.e., the ratio of cotton lint yield to rainfall are presented and discussed. Values of cotton lint yield, rainfall and $C W P$ are given in both tabular and in graphical format for each of the sixteen counties of the Texas High Plains (Figure 1). For each of these datasets we calculated frequency distributions and associated statistical parameters that include the moments of the mean, i.e., standard deviation, skewness and kurtosis, and also the mode and median values.

\subsection{Cotton Lint Yield}

The descriptive statistics for cotton lint yield are given in Table 5 and a ranking of these values from high to low, for each of the sixteen counties (Figure 1) are given in Table 6 . The mean value \pm standard deviation of dryland lint yield was $353 \pm 150 \mathrm{~kg} / \mathrm{ha}$, with a range from a low of $38 \mathrm{~kg} / \mathrm{ha}$ to a high of $1004 \mathrm{~kg} / \mathrm{ha}$. The frequency distribution of the annual values of upland lint yield (Figure 2 and Figure 3 ) indicated that the $p$-Value calculated with the $\chi^{2}$ distribution function and 38 degrees of freedom was equal to 0.108 , which is greater than the $p$-Value of 0.05 and thus we accept the null hypothesis that the data is normally distributed.

The range between the highest mean cotton lint yield ( $400 \mathrm{~kg} / \mathrm{ha}$ in Lubbock County) to lowest (252 kg/ha in Andrews County) is $148 \mathrm{~kg} / \mathrm{ha}$ or a relative

Table 5. Descriptive statistics for upland dryland cotton lint yield, annual rainfall, and calculated values of crop water productivity for all sixteen counties of the THP.

\begin{tabular}{cccc}
\hline $\begin{array}{c}\text { Statistical } \\
\text { Parameter }\end{array}$ & $\begin{array}{c}\text { Cotton Lint } \\
\text { Yield }[\mathrm{kg} / \mathrm{ha}]\end{array}$ & $\begin{array}{c}\text { Annual } \\
\text { Rainfall }[\mathrm{mm}]\end{array}$ & $\begin{array}{c}\text { Crop Water } \\
\text { Productivity }\left[\mathrm{g} / \mathrm{m}^{3}\right]\end{array}$ \\
\hline Mean & 353 & 461 & 77 \\
Standard Error & 5.73 & 4.5 & 1.49 \\
Median & 334 & 452 & 73 \\
Mode & 262 & 272 & 79 \\
Standard Deviation & 150 & 162 & 36 \\
Sample Variance & $22,386.5$ & $26,288.8$ & $1,324.4$ \\
Kurtosis & 0.596 & 0.759 & 3.472 \\
Skewness & 0.706 & 0.622 & 1.205 \\
Range & 966 & 1052 & 281 \\
Minimum & 38 & 77 & 10 \\
Maximum & 1,004 & 1,129 & 291 \\
Sum & 240,141 & 602,803 & 46,229 \\
Count & 681 & 1307 & 597 \\
Confidence Level (95\%) & 11.3 & 8.8 & 2.9 \\
\hline
\end{tabular}




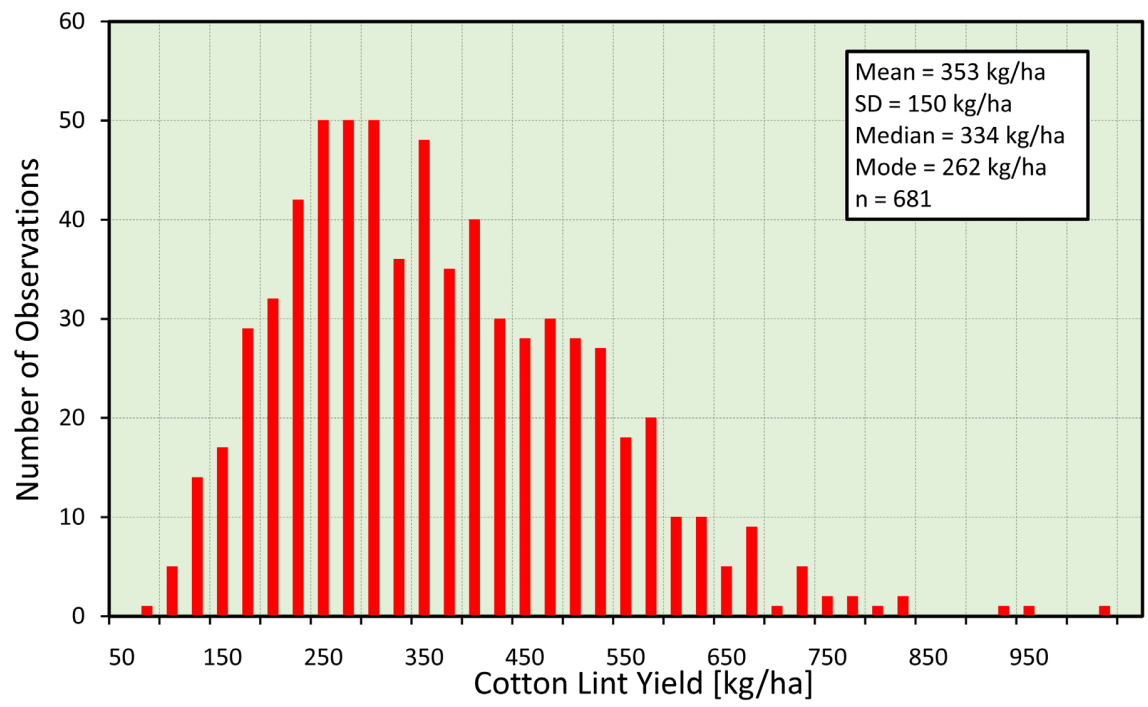

Figure 2. Frequency distribution of upland dryland lint yield values $(\mathrm{kg} / \mathrm{ha})$ for all values $(\mathrm{n}=681)$ of the sixteen counties of the THP. The overall mean, standard deviation (SD), mode and median values are given in the insert.

Table 6. Ranking of counties, high to low, for the mean annual upland cotton lint yield and mean calculated values of crop water productivity for the period from 1972 to 2018 .

\begin{tabular}{|c|c|c|c|c|}
\hline \multirow{2}{*}{ Rank } & \multicolumn{2}{|c|}{$\begin{array}{l}\text { Cotton Lint Yield } \\
{[\mathrm{kg} / \mathrm{ha}]}\end{array}$} & \multicolumn{2}{|c|}{$\begin{array}{l}\text { Crop Water Productivity } \\
\qquad\left[\mathrm{g} / \mathrm{m}^{3}\right]\end{array}$} \\
\hline & County & Value & County & Value \\
\hline 1 & Lubbock & 400 & Glasscock & 94 \\
\hline 2 & Martin & 394 & Midland & 93 \\
\hline 3 & Lynn & 385 & Martin & 91 \\
\hline 4 & Howard & 381 & Lubbock & 86 \\
\hline 5 & Dawson & 376 & Dawson & 81 \\
\hline 6 & Borden & 375 & Borden & 81 \\
\hline 7 & Glasscock & 373 & Gaines & 79 \\
\hline 8 & Crosby & 361 & Cochran & 78 \\
\hline 9 & Garza & 356 & Lynn & 76 \\
\hline 10 & Hockley & 344 & Howard & 74 \\
\hline 11 & Gaines & 335 & Yoakum & 74 \\
\hline 12 & Terry & 327 & Hockley & 73 \\
\hline 13 & Cochran & 321 & Terry & 70 \\
\hline 14 & Yoakum & 318 & Garza & 68 \\
\hline 15 & Midland & 311 & Crosby & 66 \\
\hline 16 & Andrews & 252 & Andrews & 60 \\
\hline
\end{tabular}




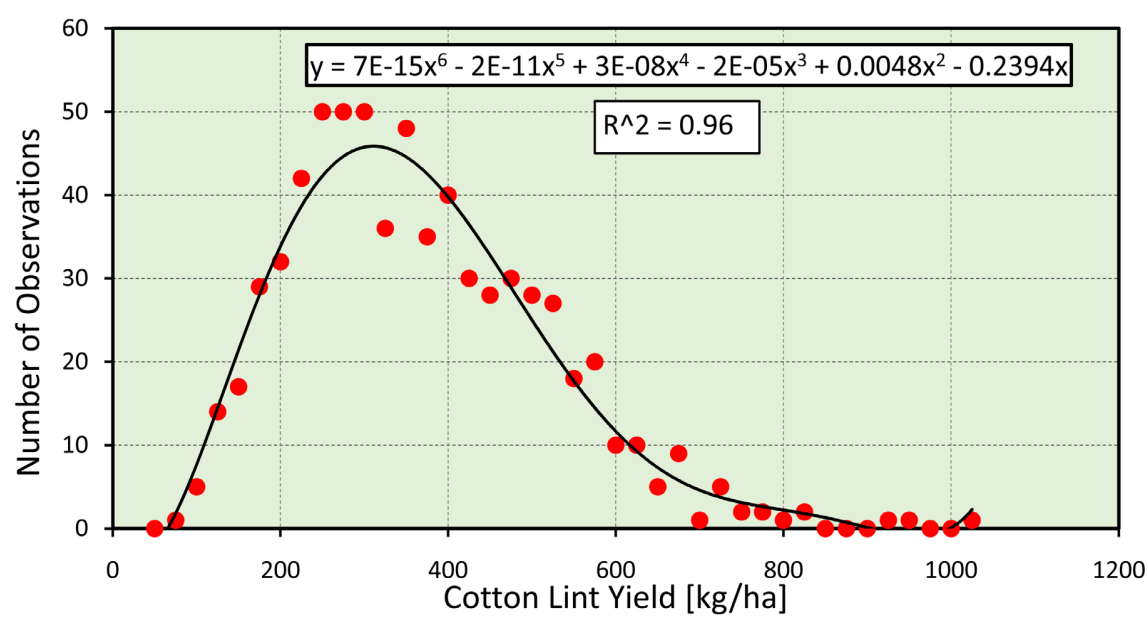

Figure 3. Frequency distribution of upland dryland lint yield $(\mathrm{kg} / \mathrm{ha})$ for the sixteen counties of the THP. The equation given is a $6^{\text {th }}$ order polynomial curve with a correlation coefficient $\left(\mathrm{R}^{2}\right)$ of 0.96 .

difference of 37\% (Table 6). For the top nine counties, Lubbock, Martin, Lynn, Howard, Dawson, Borden, Glasscock, Crosby and Garza the annual lint yield values are within $11 \%$ of each other. For the remaining counties, i.e., Hockley, Gaines, Terry, Cochran, Yoakum, Midland, and Andrews the annual mean lint yield ranged between $14 \%$ to $37 \%$, equivalent to about $92 \mathrm{~kg} / \mathrm{ha}$ from 252 to 344 $\mathrm{kg} / \mathrm{ha}$, compared to the highest mean cotton lint yield of $400 \mathrm{~kg} / \mathrm{ha}$ in Lubbock County. Two counties, Midland and Andrews (Figure 1) had the lowest annual mean lint yield values of 311 and $252 \mathrm{~kg} / \mathrm{ha}$, respectively. In general, the mean lint yield of five western counties (Cochran, Yoakum, Gaines, Andrews, and Midland) are the lowest; four central counties (Lubbock, Lynn, Dawson, Martin) have the highest annual lint yield values; and four eastern counties (Crosby, Garza, Borden, and Glasscock) are in the middle between the highest and lowest mean cotton lint yield values (Table 5, Figure 1). Similar values of cotton lint yield under dryland conditions for the THP are given by [5] [6] [45] [46] and by others.

Other statistical parameters given in Table 5 are two moments of the mean, i.e., kurtosis and skewness. Kurtosis describes the "flatness" of the frequency distribution curve (Figure 2 and Figure 3 ). Perfectly symmetrical datasets will have a kurtosis of approximately 3 and the values given in Table 5 suggest a platykurtic distribution. Likewise, skewness is a metric to indicate the symmetry of the dataset and a perfectly normal distribution has a value of zero. The average skewness for the 16 counties is 0.7 (Table 5). Other parameters given are the median and mode. The median is a measure of central tendency and ranges from $225 \mathrm{~kg} / \mathrm{ha}$ (Andrews) to $504 \mathrm{~kg} / \mathrm{ha}$ (Dawson) with a mean value of 334 $\mathrm{kg} / \mathrm{ha}$ for the sixteen counties. The mode is also a metric of central tendency and is the most frequent value in the dataset, which was $262 \mathrm{~kg} / \mathrm{ha}$. The lowest mode was $183 \mathrm{~kg} / \mathrm{ha}$ (Borden) and highest mode was $504 \mathrm{~kg} / \mathrm{ha}$ (Glasscock). 
The curve describing the frequency distribution of all the dryland cotton lint yield values $(n=681)$ is given by a sixth order polynomial equation (Figure 3 ), which has a correlation coefficient $\left(\mathrm{R}^{2}\right)$ of 0.96 . The mean value (353 kg/ha), SD of $150 \mathrm{~kg} / \mathrm{ha}$, median $(334 \mathrm{~kg} / \mathrm{ha})$ and mode $(262 \mathrm{~kg} / \mathrm{ha})$ are given in the histogram of the upland lint yield values (Figure 2).

\subsection{Rainfall}

The frequency distribution of all values $(\mathrm{n}=1307)$ of annual rainfall for the sixteen counties of the THP are plotted in Figure 4 as a histogram and as a curve in Figure 5. This histogram includes all rainfall data shown in Table 4. The

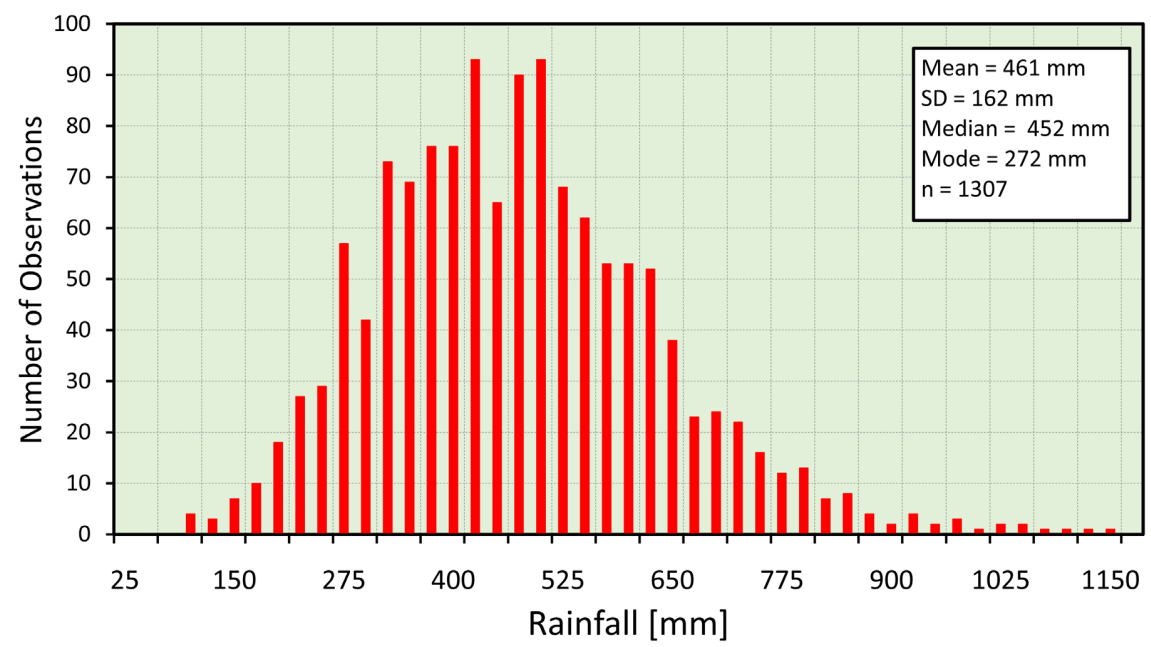

Figure 4. Frequency distribution of annual rainfall $(\mathrm{mm})$ for all values $(\mathrm{n}=1307)$ of the sixteen counties of the THP. Statistical parameters such as the standard deviation (SD) of the mean, mode and median value are given in the insert.

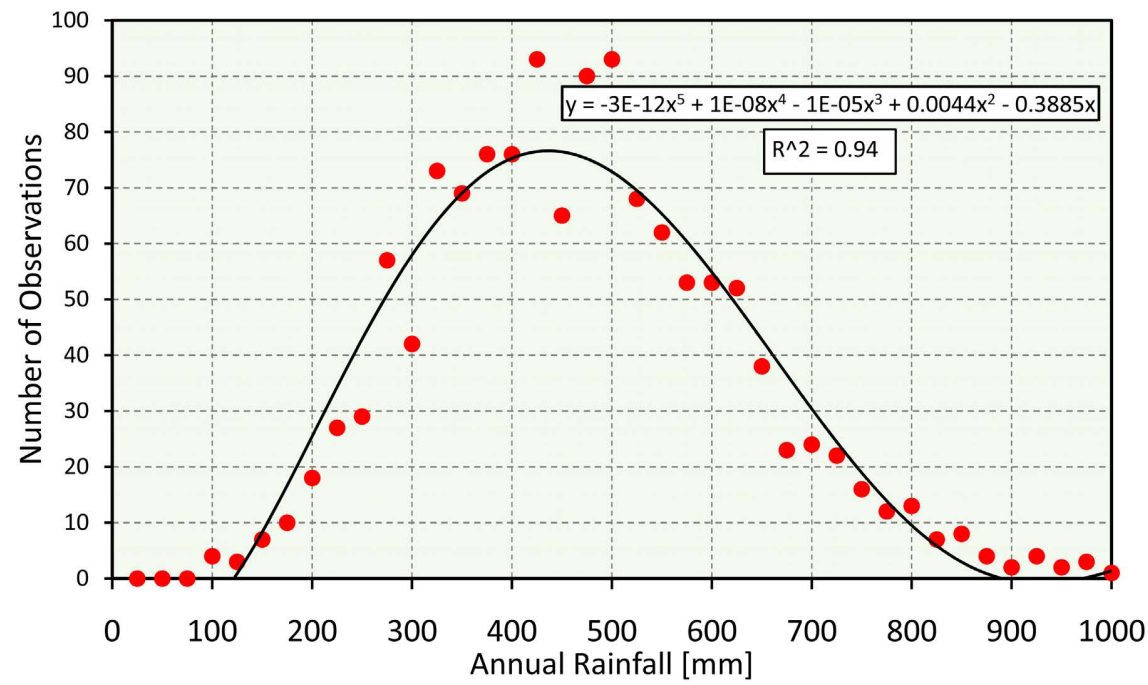

Figure 5. Frequency distribution of the annual values of rainfall for the sixteen counties of the THP. The equation given is a $5^{\text {th }}$ order polynomial curve with a correlation coefficient $\left(\mathrm{R}^{2}\right)$ of 0.94 . 
frequency distribution of the annual values of rainfall (Figure 4 and Figure 5) indicated that the $p$-Value calculated with the $\chi^{2}$ distribution function and 44 degrees of freedom was equal 0.10 , which is greater than the $p$-Value of 0.05 and thus we accept the null hypothesis that the rainfall data is normally distributed. The mean annual rainfall is $461 \mathrm{~mm}$, with a standard deviation of $162 \mathrm{~mm}$, mode of $272 \mathrm{~mm}$ and median value of $452 \mathrm{~mm}$ (Figure 4). This frequency distribution is described by a fifth order polynomial equation with a correlation coefficient $\left(\mathrm{R}^{2}\right)$ value of 0.94 (Figure 5). Descriptive statistics for the mean annual rainfall of all counties are given in Table 5.

The annual mean rainfall for the 49-year period from 1972 to 2020 for all 16 counties is plotted in Figure 6. This time-period represents the time-span for the length of cotton lint yield record. The driest county is Midland with an average rainfall of $374 \mathrm{~mm}$ ( $79 \%$ of the mean value of $475 \mathrm{~mm}$ ) and closely followed by Andrews with $380 \mathrm{~mm}$ (80\% of the mean). The two wettest counties are Garza (547 mm, 115\% of the mean) and Crosby (566 mm, 119\% of the mean). In general, rainfall increases on average by 30 to $40 \mathrm{~mm}$ from west to east. These average values of rainfall are similar to those values reported for the US cotton growing region for a 30-year average rainfall [47]. They indicated an average annual rainfall value between 400 to $500 \mathrm{~mm}$ for the sixteen counties of the THP (Figure 1) and that this average increased by $100 \mathrm{~mm}$, from 400 to $500 \mathrm{~mm}$ from west to east (see their Figure 2 in [47]).

The annual rainfall for each of the sixteen counties of the THP for a 49-year record, from 1972 to 2020 is given in Figure 7. The driest year in this time-span was 2011 with $179 \mathrm{~mm}$, followed by 1998 with $278 \mathrm{~mm}$ of rain. The 20-year period, 2001 to 2020, has recorded five of the driest years in the THP. The two wettest years were 2004 with $843 \mathrm{~mm}$ and 1986 with $736 \mathrm{~mm}$. In the 20-year span, 2001-2020, the THP recorded four of the wettest years. The overall mean \pm $\mathrm{SD}$ rainfall for the 49 -year record was $475 \pm 119 \mathrm{~mm}$ (Figure 7). This value is

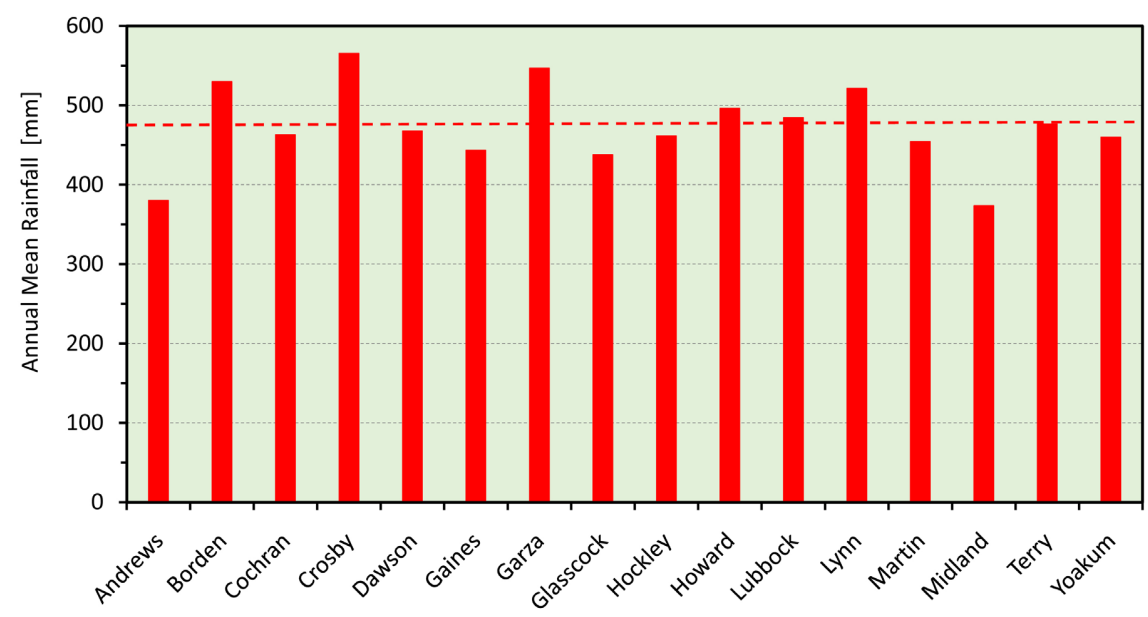

Figure 6. Annual mean rainfall (1972-2020) for each of the sixteen counties of the THP. The red dashed line is the overall mean rainfall of $475 \mathrm{~mm}$ for the entire region. 


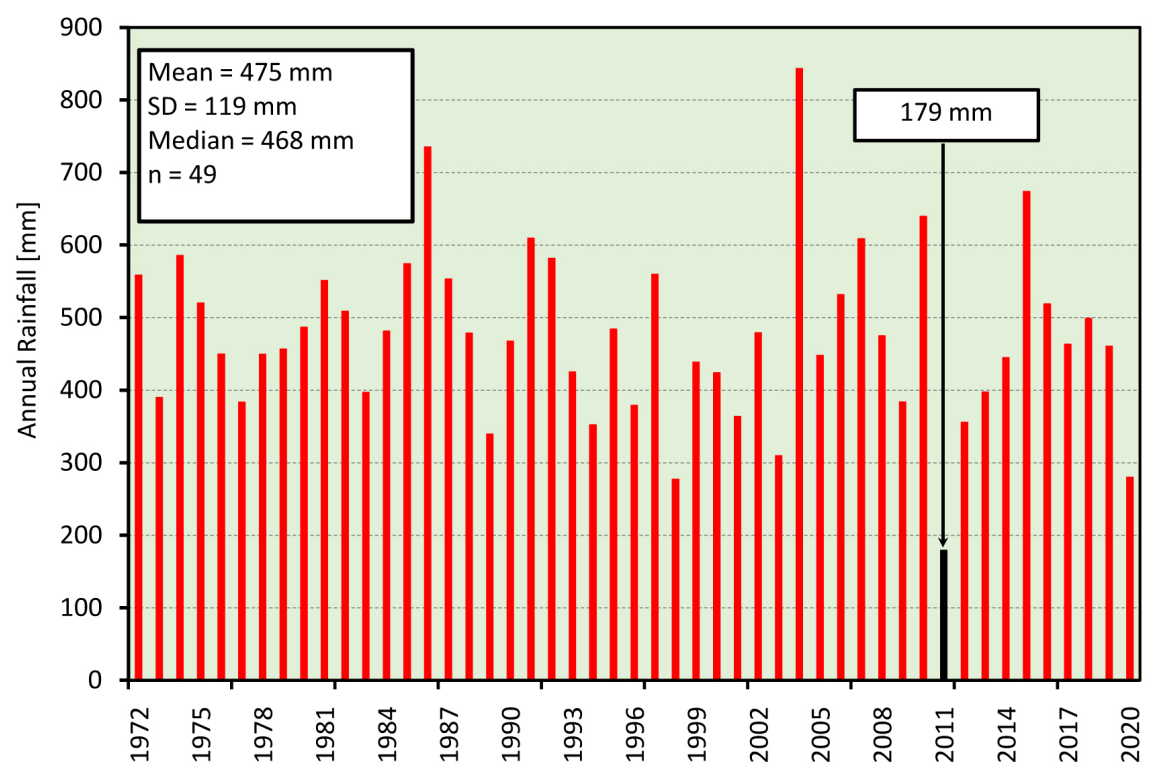

Figure 7. Annual mean rainfall (mm) for all counties of the THP between 1972 and 2020. The black bar is the record low value of $179 \mathrm{~mm}$ of rain in 2011. The mean value of rainfall is $475 \mathrm{~mm}$, with standard deviation of $119 \mathrm{~mm}$, and median value of $468 \mathrm{~mm}$.

slightly larger (3\%) when compared to the mean rainfall when including all measured values across the THP of $461 \pm 162 \mathrm{~mm}$ (Figure 4). However, the SD of all values was $36 \%$ larger, 162 vs. $119 \mathrm{~mm}$.

\subsection{Crop Water Productivity (CWP)}

Descriptive statistics for calculated values of CWP for all counties of the THP are given in Table 5, and ranking, from high to low, for each the 16 counties of the THP are given in Table 6. The value of $C W P$ as defined in Equation (1) is the ratio of lint yield $(\mathrm{kg} / \mathrm{ha})$ to annual rainfall $(\mathrm{mm})$ and thus a larger value of $C W P$ indicates more production, i.e., more lint $(\mathrm{g})$ per unit of water $\left(\mathrm{m}^{3}\right)$, which for this semiarid region is per unit of rainfall. The calculated mean values of $C W P$ have a range from a high of $94 \mathrm{~g} / \mathrm{m}^{3}$ (Glasscock) to a low of $60 \mathrm{~g} / \mathrm{m}^{3}$ (Andrews), this difference of $34 \mathrm{~g} / \mathrm{m}^{3}$ is equivalent to $36 \%$. This relative difference is similar as that measured for mean values of cotton lint yield of $400 \mathrm{~kg} / \mathrm{ha}$ (Lubbock) vs. $252 \mathrm{~kg} / \mathrm{ha}$ (Andrews) (Table 6). The top two counties with the largest CWP are Glasscock and Midland with a value of $\sim 93 \mathrm{~g} / \mathrm{m}^{3}$. This is an interesting result given that Midland was penultimate in the ranking of mean annual lint yield (Table 6). In general, the $C W P$ rankings can be grouped into four categories, i.e., 90's (Glasscock, Midland, Martin, Lubbock); 80's (Dawson, Borden, Gaines, Cochran and Lynn); 70's (Howard, Yoakum, Hockley, Terry, Garza, and Crosby); and 60's (Andrews). These values of $C W P$ fall within the range, 70 to 330 $\mathrm{g} / \mathrm{m}^{3}$ for cotton given by [48] and of 50 to $250 \mathrm{~g} / \mathrm{m}^{3}$ given by [47]. As expected, higher values of $C W P$ are for irrigated cotton lint yields.

Statistical parameters given in Table 5 include standard deviation (SD), maximum and minimum values, the moments of the mean (kurtosis and skew- 
ness), and mode and median. Values of $C W P$ are variable with a high SD of 46 $\mathrm{g} / \mathrm{m}^{3}$ (Midland) to a low SD of $26 \mathrm{~g} / \mathrm{m}^{3}$ (Cochran). The average CV across all values of $C W P$ is $47 \%$. The largest value of $C W P$ was calculated in 2010 in Cochran County with a value of $291 \mathrm{~g} / \mathrm{m}^{3}$, i.e., lint yield of $553 \mathrm{~kg} / \mathrm{ha}$ with 190 $\mathrm{mm}$ of rain. Values of $C W P>200 \mathrm{~g} / \mathrm{m}^{3}$ were recorded twice in Midland in 1998 (371 kg/ha with $143 \mathrm{~mm}$ ) and in 1977 (353 kg/ha with $174 \mathrm{~mm})$, once in Borden County in 1973 (729 kg/ha with $308 \mathrm{~mm}$ ), once in Lubbock County in 2005 (807 $\mathrm{kg} / \mathrm{ha}$ with $393 \mathrm{~mm}$ ), and once in Glasscock County in 1988 (332 kg/ha with 164 $\mathrm{mm})$. On the opposite end, values of $C W P<15 \mathrm{~g} / \mathrm{m}^{3}$ were recorded in 1974 in Borden ( $86 \mathrm{~kg} / \mathrm{ha}$ with $578 \mathrm{~mm})$ and in Terry County $(67 \mathrm{~kg} / \mathrm{ha}$ with $664 \mathrm{~mm})$ in 1973 in Andrews County (38 kg/ha and $349 \mathrm{~mm}$ ), and in 1980 in Cochran County (90 kg/ha with $640 \mathrm{~mm}$ ). Clearly, the issue here was not lack of rainfall, but rather was likely due to hail damage during the growing season. These are examples, of years with probably excessive rainfall accompanied by low ambient temperatures that negatively affected the cotton crop.

Midland County is an example that illustrates the importance of not only the total amount of rain but also of its distribution during the growing season. Midland recorded two of the largest CWP's in 1977 and in 1988; however, between 2007 and 2018 only one cotton crop, in 2010, was harvested. This high values of CWP achieved in Midland are likely to the "timing" of rainfall occurring during critical stages of boll filling and maturation [49]. Clearly, it was not the total amount of rainfall that determined the final cotton lint yield but rather it was due to its timing and distribution throughout the growing season. Also, other environmental factors, such as heat units [50], from planting to harvest [51], and management of the crop (fertilization and tillage operations) contributed to the final lint yield [52].

The statistical parameters for $C W P$ given in Table 5 indicated a kurtosis of 3.47 and a skewness of 1.20 , which is an indication of a symmetrical data set. Further the mean value of $C W P$ is $77 \mathrm{~g} / \mathrm{m}^{3}$, with a median of $73 \mathrm{~g} / \mathrm{m}^{3}$ and mode of $79 \mathrm{~g} / \mathrm{m}^{3}$ suggesting a normal distribution (Figure 8 and Figure 9). The $p$-Value calculated with the $\chi^{2}$ distribution function and 27 degrees of freedom was equal to 0.222 , which is greater than the $p$-Value of 0.05 and thus we accept the null hypothesis that the $C W P$ dataset was normally distributed. The frequency distribution of the calculated values of $C W P$ is described by the fifth order polynomial curve plotted in Figure 9. The correlation coefficient $\left(\mathrm{R}^{2}\right)$ of this curve is 0.94 .

The $C W P$ is a metric that is often used to compare crop production subject to different conditions [47]. The term $C W P$ is preferred over water use efficiency (WUE) [48] as WUE involves an efficiency term that by definition has no units [36] [37] [38]. The scaling of $C W P$ from field to a regional scale can be accomplished by using areas that are homogenous with respect to the soil and hydrological properties [53]. In our case we are using mean values of cotton lint yield that are reported at the county level with corresponding mean values of rainfall for the county. 


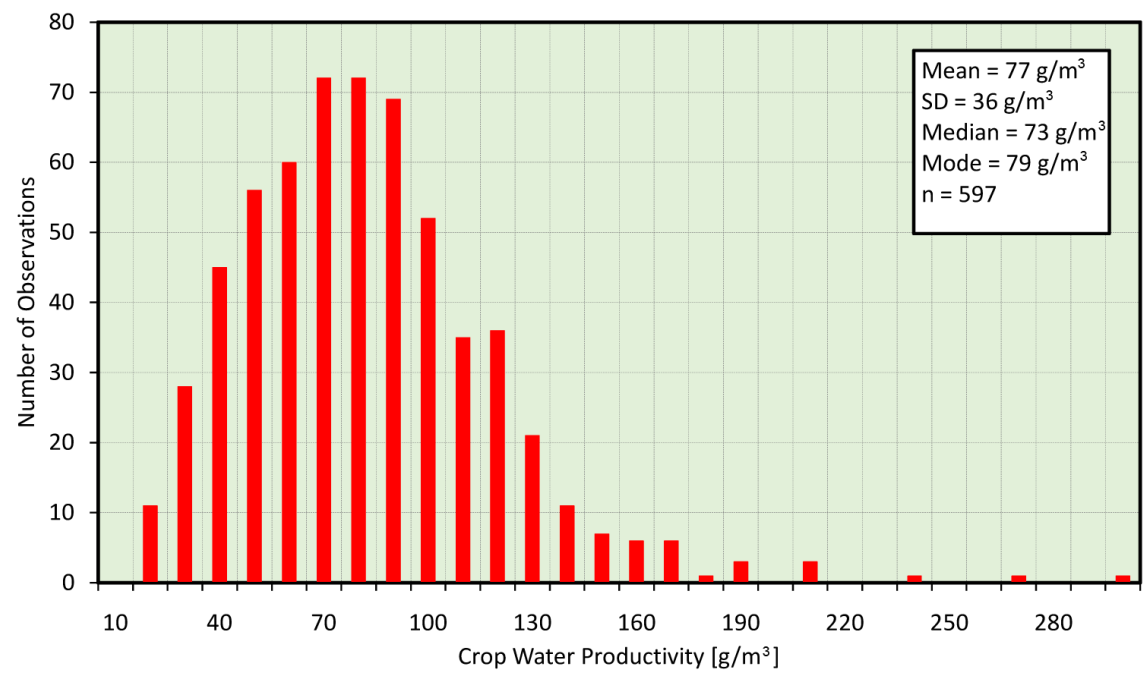

Figure 8. Frequency distribution of Crop Water Productivity $\left(C W P, \mathrm{~g} / \mathrm{m}^{3}\right)$ for all values $(n=597)$ of the sixteen counties of the THP.

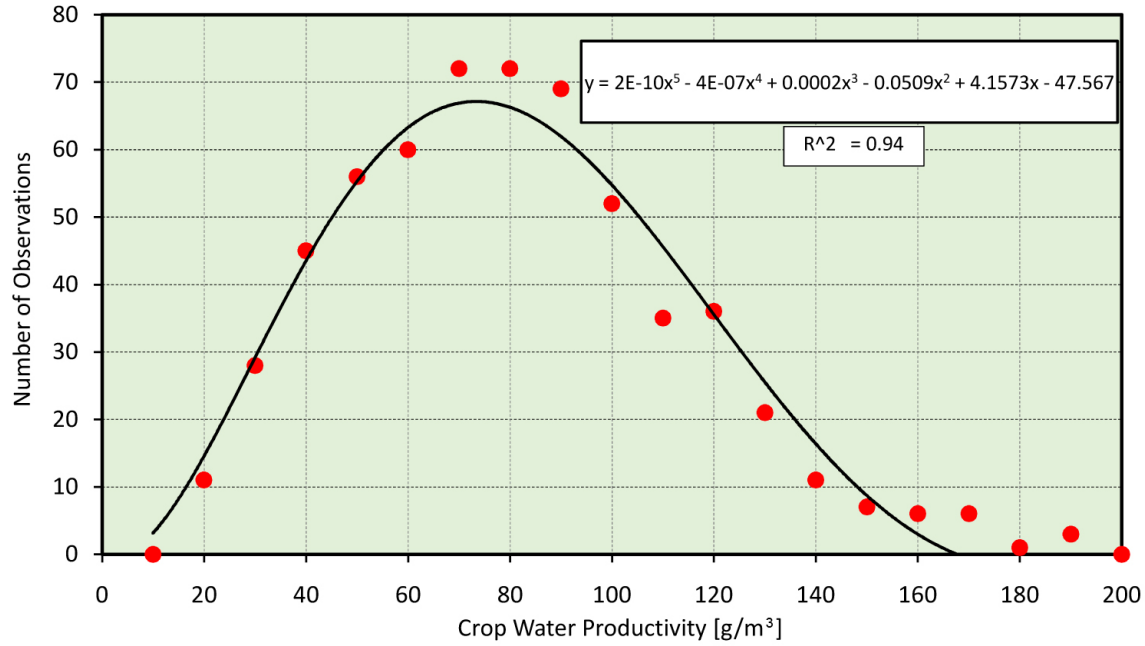

Figure 9. Frequency distribution of calculated values of Crop Water Productivity ( $C W P$, $\mathrm{g} / \mathrm{m}^{3}$ ) for the sixteen counties of the THP. The equation given is a $5^{\text {th }}$ order polynomial curve with a correlation coefficient $\left(\mathrm{R}^{2}\right)$ of 0.94 .

In a farming operation the final crop yield is a function of many factors. These include crop rotations, the amount of soil water stored in the profile, thermal units throughout the growing season, soil tillage operations, fertilization and pest management, and frequency and amount of rainfall during the growing season. In our analysis we have only considered the annual rainfall amount at the county level. Further, we assume that for the conditions of the THP and its semiarid environment, a proxy of the annual evapotranspiration (ET) at the county level is given by the annual amount of rain, i.e., $E T \approx$ Rain [41] [42] [43], and therefore this assumption allow us to calculate $C W P$ as the ratio of cotton lint yield to rainfall.

From a water management point of view, the success of a dryland cotton 
farming operation in the semiarid region of the THP primarily depends on first having adequate soil moisture at planting to germinate and emerge the planted seed. Second, once the crop is established it needs adequate rain throughout the growing season. Third, stored soil water in the profile can provide 25 to $100 \mathrm{~mm}$ of additional water [9]. However, the rainfall frequency and amount during the growing season is by far the largest contributor that will determine the cotton lint yield that is harvested. Such is the case based on the length of the record (Table 2) of cotton lint yield values (Table 5) for the THP. Since 1972, only one year 2011, a record drought (179 $\mathrm{mm}$ of rain) failed to provide a harvestable cotton crop across all counties of the THP. Midland, the southmost county of our analysis has failed to produce a cotton crop once every five years in the 1972-2018 time period. However, Midland County also has the distinction of having the largest $C W P\left(93 \mathrm{~g} / \mathrm{m}^{3}\right)$ for this time period. Further, three counties located in the South region of the THP, i.e., Glasscock, Midland and Martin County have values of $C W P>90 \mathrm{~g} / \mathrm{m}^{3}$ (Table 6) and Glasscock and Martin have only twice during this time period failed to harvest a cotton crop. This achievement is due to the excellence of the cotton farmers that manage to produce a cotton crop year-after-year under dryland conditions. This accomplishment means the success of dryland cotton production in the THP and many of the management decisions that are used in these counties can be applied to others to sustain the emerging cotton industry in the THP.

Our analysis of dryland cotton lint yield across sixteen counties of the THP is solely based on annual average values of lint yield and rainfall at the county level, and in our analysis we use average rainfall as a surrogate of annual evapotranspiration to calculate $C W P$. Our results show that dryland cotton production is a sustainable farming enterprise in the THP. Further, the largest values of $C W P$ were calculated for counties that normally experience drought and extreme environmental conditions, and yet farmers manage to produce a cotton crop most years. The significance of this result is that management schemes that these producers implement represent the future of emerging dryland cropping systems of the THP. For this purpose we have implemented a long-term project working with dryland cotton producers in Martin County. Our intent is to document and to understand their decision-making process regarding agronomic management practices. In turn, we can then use this information as input to cropping system models to analyze both the short- and long-term sustainability of dryland cropping systems across the THP.

\section{Conclusions}

Crop production in the Texas High Plains (THP) is a transition phase from using limited irrigation-water from the Ogallala aquifer to dryland practices, where rain is the only source of water. For the continued success of the emerging dryland cropping systems, we need to identify agronomic practices that are viable in this semiarid region. Thus and as first analysis, we calculated for sixteen counties 
of the THP the ratio of annual dryland cotton lint yield per unit of evapotranspiration for the period from 1972 to 2018. This ratio is called crop water productivity $(C W P)$ and has units of mass per unit volume $\left(\mathrm{g} / \mathrm{m}^{3}\right)$. In the calculation of this ratio, we assumed that for an annual water balance, the evapotranspiration amount can be approximated by the annual measured rainfall. Our results indicated that over this 47-year period only one year, 2011, failed to produce a cotton crop across all counties, which was a year with a record drought of $179 \mathrm{~mm}$ of rainfall. Average values of dryland cotton lint yield ranged from a high of 400 $\mathrm{kg} / \mathrm{ha}$ in Lubbock County to a low of $252 \mathrm{~kg} / \mathrm{ha}$ in Andrews County. However, counties with the largest values of $C W P>90 \mathrm{~g} / \mathrm{m}^{3}$ were Glasscock, Midland and Martin County. This is a significant result as these counties are geographically located in the southern region of the THP, and are subject to extreme environmental conditions, and still farmers manage to produce a cotton crop in most years. Our conclusion is that agronomic practices used by these cotton producers need to be studied and adopted in other counties of the THP. For this purpose, we have established a long-term pilot project with cotton farmers of Martin County with the aim of studying their management practices. Our working hypothesis is that the management production practices currently used by Martin County cotton farmers represent the future schemes that may need to be adopted in other counties of the THP to sustain the emerging dryland cropping systems across the THP.

\section{Acknowledgements}

The input from discussions held at meetings and workshops with Martin County Cotton Growers Association is recognized and appreciated.

\section{Declarations}

Mention of trade names or commercial products in this publication is solely for the purpose of providing specific information and does not imply recommendations or endorsement by the US Department of Agriculture. The USDA is an equal opportunity provider and employer.

\section{Conflicts of Interest}

The authors declare no conflicts of interest regarding the publication of this paper.

\section{References}

[1] Arneson, E.P. (1921) Early Irrigation in Texas. The Southwestern Historical Quarterly, 25, 121-113. https://texashistory.unt.edu/ark:/67531/metapth101082/m1/127/

[2] Musick, J.T., Pringle, F.B., Harman, W.L. and Stewart, B.A. (1990) Long-Term Irrigation Trends: Texas High Plains. Applied Engineering in Agriculture, 6, 717-724. https://doi.org/10.13031/2013.26454

[3] Colaizzi, P.D., Gowda, P.H., Marek, T.H. and Porter, D.O. (2009) Irrigation in the 
Texas High Plains: A Brief History and Potential Reductions in Demand. Irrigation and Drainage, 58, 257-274. https://doi.org/10.1002/ird.418

[4] Burnett, E. and Fisher, C.E. (1954) Correlation of Soil Moisture and Cotton Yields. Soil Science Society of America Journal, 18, 127-129. https://doi.org/10.2136/sssaj1954.03615995001800020003x

[5] Burnett, E. and Moldenhauer, W.C. (1957) Using Rainfall Records as Guides to Predict Yields of Cotton on Drylands of the High and Rolling Plains of Texas. Texas Agricultural Experiment Station in cooperation with the USDA, College Station, Texas, Miscellaneous Publication No. 223, 8.

[6] Howell, T.A., Evett, S.R., Tolk, J.A. and Schneider, A.D. (2004) Evapotranspiration of Full-, Deficit-Irrigated, and Dryland Cotton on the Northern Texas High Plains. Journal of Irrigation and Drainage Engineering, 130, 277-285. https://doi.org/10.1061/(ASCE)0733-9437(2004)130:4(277)

[7] Bloodworth, M.E. and Gillett, P.T. (1984) IRRIGATION: Handbook of Texas Online. Texas State Historical Association, Austin. https://tshaonline.org/handbook/online/articles/ahi01

[8] Opie, J. (2000) Ogallala: Water for a Dry Land. 2nd Edition, University of Nebraska Press, Lincoln, $477 \mathrm{p}$.

[9] Lascano, R.J., Leiker, G.R., Goebel, T.S., Mauget, S.A. and Gitz III, D.C. (2020) Water Balance of Two Major Soil Types of the Texas High Plains: Implications for Dryland Crop Production. Open Journal of Soil Science, 10, 274-297. https://doi.org/10.4236/ojss.2020.107015

[10] Beaumont, P. (1985) Irrigated Agriculture and Ground-Water Mining on the High Plains of Texas, USA. Environmental Conservation, 12, 119-130. https://doi.org/10.1017/S0376892900015538

[11] Scanlon, B.R., Faunt, C.C., Longuevergne, L., Reedy, R.C., Alley, W.M., McGuire, V.L. and McMahon, P.B. (2012) Groundwater Depletion and Sustainability of Irrigation in the US High Plains and Central Valley. Proceedings of the National Academy of Sciences of the United States of America, 109, 9320-9325. https://doi.org/10.1073/pnas.1200311109

[12] McGuire, V.L. (2001) Water-Level Changes in the High Plains Aquifer, 1980 to 1999. U.S. Geological Service, Reston, Publication USGS FS-029-01, 2 p.

[13] Lee, J.G. (1987) Risk Implications of the Transition to Dryland Agricultural Production on the Texas High Plains. Ph. D. Dissertation, ProQuest Dissertations Publishing, No. 8808787, Texas A\&M University, College Station, 260 p. https://doi.org/10.3133/fs02901

[14] Terrell, B.L., Johnson, P.N. and Segarra, E. (2002) Ogallala Aquifer Depletion: Economic Impact on the Texas High Plains. Water Policy, 4, 33-46. https://doi.org/10.1016/S1366-7017(02)00009-0

[15] Chen, Y., Marek, G.W., Marek, T.H., Moorhead, J.E., Heflin, K.R., Brauer, D.K., Gowda, P.H. and Srinivasan, R. (2018) Assessment of Alternative Agricultural Land Use Options for Extending the Availability of the Ogallala Aquifer in the Northern High Plains of Texas. Hydrology, 5, Article No. 53.

https://doi.org/10.3390/hydrology5040053

[16] Mauget, S., Marek, G., Adhikari, P., Leiker, G., Mahan, J., Payton, P. and Ale, S. (2020) Optimizing Dryland Crop Management to Regional Climate Via Simulation. Part I: U.S. Southern High Plains Cotton Production. Frontiers Sustainable Food Systems, 3, Article No. 120. https://doi.org/10.3389/fsufs.2019.00120 
[17] Mauget, S., Kothari, K., Leiker, G., Emendack, Y., Xin, Z., Hayes, C., Ale, S. and Baumhardt, L.R. (2020) Optimizing Dryland Crop Management to Regional Climate. Part II: U.S. Southern High Plains Grain Sorghum Production. Frontiers Sustainable Food Systems, 3, Article No. 119. https://doi.org/10.3389/fsufs.2019.00119

[18] Baumhardt, R.L., Marek, G. and Brauer, D. (2020) Trends in Runoff from Dryland, Cropped Fields on the Texas High Plains, and Implications for their Management. Frontiers Sustainable Food Systems, 4, Article ID: 529319. https://doi.org/10.3389/fsufs.2020.529319

[19] Baumhardt, R.L., Dockal, J.R., Johnson, G.L., Brauer, D.K. and Schwartz, R.C. (2020) Controlling Stormwater Runoff that Limits Water Availability and Dryland Crop Productivity. Frontiers Sustainable Food Systems, 4, Article ID: 533687. https://doi.org/10.3389/fsufs.2020.533687

[20] Ale, S., Himanshu, S.K., Mauget, S.A., Hudson, D., Goebel, T.S., Liu, B., Baumhardt, R.L., Bordovsky, J.P., Brauer, D.K., Lascano, R.J. and Gitz III., D.C. (2021) Simulated Dryland Cotton Yield Response to Selected Scenario Factors Associated with Soil Health. Frontiers Sustainable Food Systems, 4, Article ID: 617509. https://doi.org/10.3389/fsufs.2020.617509

[21] Mitchell-McCallister, D., McCullough, R., Johnson, P. and Williams, R.B. (2021) An Economic Analysis on the Transition to Dryland Production in Deficit-Irrigated Cropping Systems of the Texas High Plains. Frontiers Sustainable Food Systems, 5, Article ID: 531601. https://doi.org/10.3389/fsufs.2021.531601

[22] Lascano R.J. and Nelson, J.R. (2014) Circular Planting to Enhance Rainfall Capture in Dryland Cropping Systems at the Landscape Scale: Measurement and Simulation. In: Ahuja, L.R., Ma, Liwang and Lascano, R.J., Eds., Practical Applications of Agricultural Systems Models to Optimize the Use of Limited Water, Vol. 5, American Society of Agronomy, Madison, 85-111. https://doi.org/10.2134/advagricsystmodel5.c4

[23] Lyle, W.M. and Dixon, D.R. (1977) Basin Tillage for Rainfall Retention. Transactions ASABE, 20, 1013-1017. https://doi.org/10.13031/2013.35693

[24] Jones, O.R. and Stewart, B.A. (1990) Basin Tillage. Soil Tillage Research, 18, 249-265. https://doi.org/10.1016/0167-1987(90)90064-K

[25] Unger, P.W. and Parker, J.J. (1976) Evaporation Reduction from Soil with Wheat, Sorghum, and Cotton Residues. Soil Science Society of America Journal, 40, 938-942. https://doi.org/10.2136/sssaj1976.03615995004000060035x

[26] Lascano, R.J. and Baumhardt, R.L. (1996) Effects of Crop Residue on Soil and Plant Water Evaporation in a Dryland Cotton System. Theoretical Applied Climatology, 54, 69-84. https://doi.org/10.1007/BF00863560

[27] Harman, W.L., Michels, G.J. and Wiese, A.F. (1989) A Conservation Tillage System for Profitable Cotton Production in the Central Texas High Plains. Agronomy Journal, 81, 615-618. https://doi.org/10.2134/agronj1989.00021962008100040013x

[28] Lascano, R.J. (2021) Transition from Deficit-Irrigation to Dryland Crop Production. Frontiers Sustainable Food Systems, 5, Article ID: 707782.

https://doi.org/10.3389/fsufs.2021.707782

[29] Lascano, R.J. (2000) A General System to Measure and Calculate Daily Crop Water Use. Agronomy Journal, 92, 821-832. https://doi.org/10.2134/agronj2000.925821x

[30] Jones, O.R., Eck, H.V., Smith, S.J., Coleman, G.A. and Hauser, V.L. (1985) Runoff, Soil, and Nutrient Losses from Rangeland and Dry-Farmed Cropland in the Southern High-Plains. Journal of Soil and Water Conservation, 40, 161-164. 
[31] Brakensiek, D.C., Osborn, H.B. and Rawls, W.J. (1979) Field Manual for Research in Agricultural Hydrology. Agricultural Handbook No. 224. United States Department of Agriculture, Washington DC, 547 p. https://naldc.nal.usda.gov/download/CAT87209759/PDF

[32] George, P.G., Mace, R.E. and Petrossian, R. (2011) Aquifers of Texas. Report 380, 182 pp. https://www.twdb.texas.gov/groundwater/aquifer/index.asp

[33] USDA-ARS, Natural Resources Conservation Service (NRCS)-Texas (n.d.) General Soil Map of Texas. https://www.nrcs.usda.gov/wps/portal/nrcs/main/tx/soils/

[34] Brown, C.N. (1956) The Origin of Caliche on the Northeastern Llano Estacado, Texas. The Journal of Geology, 64, 1-15. https://doi.org/10.1086/626313

[35] Reeves Jr., C.C. (1970) Origin, Classification, and Geologic History of Caliche on the Southern High Plains, Texas and Eastern New Mexico. The Journal of Geology, 78, 352-362. https://doi.org/10.1086/627521

[36] Sinclair, T.R., Tanner, C.B. and Bennett, J.M. (1984) Water-Use Efficiency in Crop Production. BioScience, 34, 36-40. https://doi.org/10.2307/1309424

[37] Blum, A. (2009) Effective use of water (EUW) and not Water-Use Efficiency (WUE) is the Target of Crop Yield Improvement under Drought Stress. Field Crops Research, 112, 119-123. https://doi.org/10.1016/j.fcr.2009.03.009

[38] Jones, H. (2009) Chapter No. 2. What is Water Use Efficiency? In: Bacon, M., Ed., Water Use Efficiency in Plant Biology, Wiley-Blackwell, Hoboken, 27-41.

[39] Lascano, R.J., Baumhardt, R.L., Hicks, S.K. and Heilman, J.L. (1994) Soil and Plant Water Evaporation from Strip-Tilled Cotton: Measurement and Simulation. Agronomy Journal, 86, 987-994.

https://doi.org/10.2134/agronj1994.00021962008600060011x

[40] United States Department of Agriculture. National Agricultural Statistics Service (NASS).

https://quickstats.nass.usda.gov/results/23F8D121-7F98-3A1A-9ABA-E0EF835A53 $\underline{02}$

[41] Sellers, W.D. (1965) Physical Climatology. University of Chicago Press, Chicago, $272 \mathrm{p}$.

[42] Eagleson, P.S. (1978) Climate, Soil and Vegetation. 1. Introduction to Water Balance Dynamics. Water Resources Research, 14, 705-712. https://doi.org/10.1029/WR014i005p00705

[43] Eagleson, P.S. (1978) Climate, Soil and Vegetation. 6. Dynamics of the Annual Water Balance. Water Resources Research, 14, 749-764. https://doi.org/10.1029/WR014i005p00749

[44] Chen, S.-L. and Miranda, M.J. (2008) Modeling Texas Dryland Cotton Yields, With Application to Crop Insurance Actuarial Rating. Journal of Agricultural and Applied Economics, 40, 239-252. https://doi.org/10.1017/S107407080002808X

[45] Ralston, W., Krieg, D.R. and Gerik, T. (2003) Management Strategies for Dryland Cotton Production in West Texas. 2013 Beltwide Cotton Proceedings, Nashville, 6-10 January 2003, 1674-1677.

https://www.cotton.org/beltwide/proceedings/getPDF.cfm?year=2003\&paper=I018. pdf

[46] Bordovsky, J.P., Mustian, J.T., Ritchie, G.L. and Lewis, K.L. (2015) Cotton Irrigation Timing with Variable Seasonal Irrigation Capacities in the Texas South Plains. Applied Engineering in Agriculture, 31, 883-897. https://doi.org/10.13031/aea.31.10953 
[47] Barnes, E.M., Campbell, B.T., Vellidis, G., Porter, W.M., Payero, J.O., Leib, B.G., Sui, R., Fisher, D.K., Anapalli, S. Colaizzi, P.D., Bordovsky, J.P., Porter, D.O., Ale, S., Mahan, J., Taghvaeian, S. and Thorp, K.R. (2020) Forty Years of Increasing Cotton's Water Productivity and Why the Trend will Continue. Applied Engineering in Agriculture, 36, 457-478. https://doi.org/10.13031/aea.13911

[48] Zwart, S.J. and Bastiaanssen, W.G.M. (2004) Review of Measured Crop Water Productivity Values for Irrigated Wheat, Rice, Cotton and Maize. Agricultural Water Management, 69, 115-133. https://doi.org/10.1016/j.agwat.2004.04.007

[49] Jalota, S.K., Sood, Anil, Chahal, G.B.S. and Choudhury, B.U. (2006) Crop Water Productivity of Cotton (Gossypium hirsutum L.), Wheat (Triticum aestivum L.) System as Influenced by Deficit Irrigation, Soil Texture and Precipitation. Agricultural Water Management, 84, 137-146. https://doi.org/10.1016/j.agwat.2006.02.003

[50] Peng, S., Krieg, D.R. and Hicks, S.K. (1989) Cotton Lint Yield Response to Accumulated Heat Units and Soil Water Supply. Field Crops Research, 19, 253-262. https://doi.org/10.1016/0378-4290(89)90097-X

[51] Lascano, R.J., Baumhardt, R.L., Goebel, T.S., Baker, J.T. and Gitz III, D.C. (2017) Irrigation Termination Thermal Time and Amount on Cotton Lint Yield and Fiber Quality. Open Journal of Soil Science, 7, 216-234.

https://doi.org/10.4236/ojss.2017.79016

[52] Lascano, R.J., Krieg, D.R., Baker, J.T., Goebel, T.S. and Gitz III, D.C. (2015) Planting Cotton in a Crop Residue in a Semiarid Climate: Water Balance and Lint Yield. Open Journal of Soil Science, 5, 236-249. https://doi.org/10.4236/ojss.2015.510023

[53] Wesseling, J.G. and Feddes, R.A. (2006) Assessing Crop Water Productivity from Field to Regional Scale. Agricultural Water Management, 86, 30-39.

https://doi.org/10.1016/j.agwat.2006.06.011 